Dunamis: Jurnal Teologi dan Pendidikan Kristiani

Volume 2, Nomor 2 (April 2018)

ISSN 2541-3937 (print), 2541-3945 (online)

http://www.sttintheos.ac.id/e-journal/index.php/dunamis

\title{
Pentakostalisme dan Aksi Sosial: Analisis Struktural Kisah Para Rasul 2:41-47
}

\author{
Yushak Soesilo \\ Program Studi Teologi Sekolah Tinggi Teologi Intheos Surakarta \\ yushak@sttintheos.ac.id
}

\begin{abstract}
The Pentecostal Movement is a Christian movement that puts the power and work of the Holy Spirit at the first place. This movement sought to bring back the biblical Christianity as experienced by the early church. As the early church experienced a rapid growth of new souls, so it is with today's Pentecostal churches. The problem that arises is often in the effort to win the soul there is a dichotomy between power ministry, as emphasized by the Pentecostal movement, with social action. Some churches emphasize only one aspect of the ministry. Through a structural analysis approach to Acts 2: 41-47 the researcher seeks to find the ideal formulation in an attempt to win souls as in the experience of the early church. Through this approach the result is that the power ministry and social action must be carried out by the church at the same time and in balance that ultimately make the effort to win souls effectively.
\end{abstract}

Keywords: pentecostalism; semiotics; structural analysis; social action; the acts of the apostles

\begin{abstract}
Abstrak
Gerakan Pentakostalisme adalah gerakan orang Kristen yang mengutamakan kuasa dan karya Roh Kudus. Gerakan ini berusaha untuk mengembalikan kekristenan yang Alkibiah sebagaimana yang dialami oleh gereja mula-mula. Sebagaimana gereja mula-mula yang mengalami pertumbuhan jiwa baru yang pesat, demikian halnya dengan gereja-gereja Pentakosta masa kini yang juga mengalaminya. Permasalahan yang muncul adalah seringkali dalam usaha untuk memenangkan jiwa ada dikotomi antara pelayanan dengan kuasa, sebagaimana yang ditekankan oleh gerakan Pentakostalisme, dengan aksi sosial. Beberapa gereja menekankan hanya pada satu segi dari pelayanan tersebut. Melalui pendekatan analisis struktural terhadap Kisah Para Rasul 2:41-47 peneliti hendak mencari formulasi yang ideal dalam usaha untuk memenangkan jiwa sebagaimana pengalaman gereja mula-mula. Melalui pendekatan tersebut diperoleh hasil bahwa pelayanan kuasa dan aksi sosial harus dijalankan oleh gereja secara bersamaan dan seimbang yang pada akhirnya membuat usaha untuk memenangkan jiwa berlangsung secara efektif.
\end{abstract}

Kata Kunci: pentakostalisme; semiotika; analisis struktural; aksi sosial; kisah para rasul 


\section{PENDAHULUAN}

Pentakosta dalam Perjanjian Lama dirayakan sebagai hari pengucapan syukur kepada Tuhan atas panen yang melimpah. Istilah Pentakosta sendiri berasal dari bahasa Yunani pente yang berarti lima, dan konta yang berarti puluh. Pentakosta dirayakan lima puluh hari setelah perayaan Paskah. Pada hari tersebut orang Israel mempersembahkan korban hulu hasil sehingga disebut sebagai "pesta penuaian" (Im. 23:15-21; Ul. 28:26-31). Dalam Perjanjian Baru istilah Pentakosta ditemukan dalam Kisah Para Rasul, yang menunjuk kepada peristiwa pencurahan Roh Kudus kepada murid-murid Yesus yang sedang berkumpul di Yerusalem. Peristiwa pencurahan Roh Kudus di Yerusalem tersebut kemudian menjadi tonggak berdirinya gereja, yang dalam setiap misinya mengandalkan kuasa Roh Kudus.

\section{Pentakostalisme}

sendiri didefinisikan sebagai suatu paham, gerakan, atau aliran dan ajaran karya Roh Kudus seperti pada hari Pentakosta di Yerusalem. ${ }^{1}$ Gerakan Pentakostalisme (Pentecostalism Movement) adalah gerakan orang Kristen yang mengutamakan kuasa dan karya Roh

\footnotetext{
${ }^{1}$ Daniel Sutoyo, Gerakan Pentakostalisme: Sejarah Kebangunan Rohani Yang Mewarnai Dunia Dan Injil Bagi Bangsa-Bangsa (Sukoharjo: Born Win's Publishing, 2011), 5.
}

Kudus. ${ }^{2}$ Gerakan ini adalah usaha untuk kembali kepada kekristenan yang Alkitabiah sebagaimana yang dialami oleh gereja mula-mula. 3 Gerakan Pentakostalisme membawa penekanan pada terhadap pribadi dan karya Roh Kudus bagi orang percaya. ${ }^{4}$

$$
\text { Pelayanan dari gerakan }
$$

Pentakostalisme memiliki ciri khas tersendiri yang disebut dengan pelayanan dengan kuasa, yaitu pelayanan yang menekankan pada kuasa Roh Kudus dengan disertai tanda-tanda dan mujizatmujizat. ${ }^{5}$ Meskipun menekankan pada pelayanan kuasa bukan berarti bahwa gerakan Pentakostalisme mengabaikan karunia rohani yang dianggap kurang nyata. ${ }^{6}$ Pelayanan dengan kuasa tersebut bertujuan untuk memenangkan jiwa melalui pemberitaan Injil dengan semangat dan kuasa Roh Kudus.

Permasalahan yang muncul dalam kaitannya dengan usaha untuk memenangkan jiwa, gereja seringkali membuat dikotomi antara penginjilan dengan aksi sosial. Ada yang lebih menekankan pada penginjilan sehingga

\footnotetext{
2 Ibid, 6.

${ }^{3}$ Andreas Sudjono, "Pentakostalisme," Jurnal Antusias 1, no. 2 (May 1, 2011): 6-12, accessed March 13, 2018, http://sttintheos.ac.id/ejournal/index.php/antusias/article/view/80/79. ${ }^{4}$ Ibid.

${ }^{5}$ Sutoyo, Gerakan Pentakostalisme: Sejarah Kebangunan Rohani Yang Mewarnai Dunia Dan Injil Bagi Bangsa-Bangsa, 17. ${ }^{6}$ Ibid.
} 
menganggap bahwa pengalaman supranatural lebih penting dibandingkan dengan aksi sosial, dan sebaliknya ada juga yang mengaggap bahwa aksi sosial adalah sudah merupakan penginjilan itu sendiri. Penginjilan seringkali dikategorikan dalam dunia spiritual, sedangkan aksi sosial dikategorian dalam dunia fisik dan sifatnya sementara. 7 Penginjilan juga sering dikategorikan sebagai proklamasi Kerajaan Allah, sedangkan aksi sosial adalah demonstrasi Kerajaan Allah. ${ }^{8}$ Gereja seringkali menempatkan dirinya dalam salah satu dari kedua kutub tersebut.

Kisah Para Rasul 2:41-47 adalah salah satu teks yang menceritakan bagaimana kehidupan jemaat mula-mula. Jemaat mula-mula mengalami perkembangan yang sangat pesat, bahkan dapat dikatakan sebagai suatu ledakan jiwa. Apa yang terjadi dalam Kisah Para Rasul tersebut kemudian juga dinapaktilasi oleh gerakan Pentakostalisme, di mana gereja-gereja yang beraliran Pentakosta juga mengalami pertumbuhan jiwa dengan sangat pesat. Pertumbuhan pesat yang dialami oleh gereja-gereja Pentakosta dapat diduga karena mengadopsi praktikpraktik dalam kehidupan jemaat mula-

\footnotetext{
${ }^{7}$ Melba Padilla Maggay, Transformasi Masyarakat: Refleksi Keterlibatan Sosial Kristen (Jakarta: Cultivate Publishing, 2004), 11.

${ }^{8}$ Ken Gnanakan, Teologi Misi: Kepedulian Kerajaan Allah, ed. Yusak Tanasyah (Jakarta: YWAM Publishing Indonesia, 1995), 230-231.
}

mula tersebut. Penelitian ini bertujuan untuk menemukan formulasi yang menghasilkan pertumbuhan jiwa secara pesat dalam jemaat mula-mula di Yerusalem pasca peristiwa Pentakosta melalui pendekatan struktural terhadap teks Kisah Para Rasul 2:41-47.

\section{METODE PENELITIAN}

Pendekatan yang digunakan dalam menganalisa teks Kisah Para Rasul 2:41-47 ini adalah melalui pendekatan analisis struktural. Analisis struktural atau semiotik adalah merupakan suatu pendekatan terhadap teks Alkitab yang menganggap bahwa dalam suatu teks penulis dengan sengaja memberikan simbol bahasa yang saling berkaitan satu dengan yang lainnya dengan maksud untuk menggambarkan jalan pikiran penulis. ${ }^{9}$ Simbol-simbol bahasa tersebut ditempatkan dengan seimbang (parallel), yang membentuk suatu kesejajaran baik dalam kesamaan maupun dalam kontrasnya, yang dikenal sebagai paralelismus membrorum. ${ }^{10}$ Kesejajaran tersebut dapat ditemukan baik

\footnotetext{
${ }^{9}$ P. A. Didi Tarmedi, “Analisis Naratif: Sebuah Metode Kristiani Hermeneutika Kitab Suci," MELINTAS 29, no. 3 (July 14, 2014): 331-360, accessed February 25, 2018, http://journal.unpar.ac.id/index.php/melintas/article /view/902/889.

${ }^{10}$ Yushak Soesilo, "Doktrin Oneness

Pentacostalism," Jurnal Antusias 2, no. 1 (January 5, 2012): 53-67, accessed March 4, 2018, http://sttintheos.ac.id/ejournal/index.php/antusias/article/view/60/59.
} 
dalam bentuk kata, frase, kalimat, maupun dalam bentuk gagasan/ inplisit.

Tujuan dari metode semiotik ini adalah untuk mendapatkan makna selain daripada prosedur penafsiran. ${ }^{11}$ Prinsip penting dalam semiotik ini adalah bahwa harus berangkat dari teks, menganalisa teks, dan kemudian menerapkan kembali hsil analisa tersebut ke dalam teks, di mana metode di dalam menganalisa tersebut bukanlah secara eksplisit muncul dari permukaan teks namun hanya ada di dalam pikiran penganalisa. ${ }^{12}$ Apa yang tidak nampak dari permukaan teks tersebut kemudian dibawa kepada makna yang terang. ${ }^{13}$

\section{ANALISIS DAN HASIL}

\section{Teks Kisah Para Rasul 2:41-47}

41. sesungguhnya orang-orang yang menerima perkataan itu memberi diri dibaptis dan ditambahkan kepada mereka kira-kira tiga ribu jiwa

42. dan mereka bertekun dalam pengajaran para rasul dan dalam persekutuan, dan dalam pemecahan roti dan dalam doa-doa.

43. dan ketakutan memenuhi setiap jiwa, dan banyak mujizat dan tanda dikerjakan oleh para rasul.

\footnotetext{
${ }^{11}$ Jean Calloud, "A Few Comments on Structural Semiotics: A Brief Review of A Method and Some Explanation of Procedures," Semeia 15 (1979): 5182.

${ }^{12}$ Ibid.

${ }^{13}$ Ibid.
}

44. Dan semua orang yang telah menjadi percaya tetap bersatu, dan mereka memiliki semua kesamaan,

45. dan selalu ada dari mereka yang menjual sebidang tanah dan harta milik, dan membagikannya kepada semua orang sesuai dengan keperluan masing-masing.

46. tiap-tiap hari mereka bertekun dengan sehati dalam Bait Allah, dan mereka memecahkan roti dari rumah ke rumah, saling berbagi makanan dengan sukacita dan tulus hati

47. mereka memuji Allah, dan mereka mendapatkan kasih semua orang. Dan tiaptiap hari Tuhan menambahkan kepada gereja orang-orang yang diselamatkan.

\section{Batasan Teks}

Perikop Kisah Para Rasul 2:41-47 tersebut merupakan satu kesatuan unit yang ditandai dengan adanya inklusio, yaitu ayat 41 dan $47 \mathrm{~b}$, yang dalam kedua ayat pembuka dan penutup tersebut samasama mengetengahkan penambahan jumlah jiwa setelah peristiwa Pentakosta di Yerusalem. 


\section{Analisis Struktural}

Peneliti membuat struktur teks tersebut dalam pola kiasme $\mathrm{ABCC}$ 'B' $\mathrm{A}$ ' yang susunannya adalah sebagai berikut:

A : jumlah orang percaya bertambah (ay.

B : bertekun dalam pengajaran para rasul dan dalam persekutuan (ay. 42)

C : aksi para rasul: mengadakan banyak mujizat dan tanda (ay. 43)

C' : aksi jemaah: kepedulian sosial (ay. $44-45)$

B' : bertekun di Bait Allah dan bersekutu di rumah masing-masing secara bergiliran (ay. $46-47 b$ )

A' : jumlah orang percaya bertambah tiap-tiap harinya (ay. 47c)

Korespondensi antara ayat 41 dengan ayat 47c dapat ditemukan dalam kesamaan beberapa kata yang dipakai, antara lain kata kerja dasar

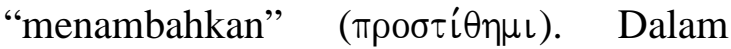
kedua ayat tersebut Lukas menggunakan tensis yang berbeda, yaitu aorist ( $(\pi \rho 0 \sigma \in \tau \dot{i} \theta \in \iota)$ pada ayat 47c. Tensis aorist digunakan untuk menyatakan peristiwa yang pernah terjadi. ${ }^{14}$ Perbedaan tensis yang digunakan dalam dua ayat yang

\footnotetext{
${ }^{14}$ J.W. Wenham, Bahasa Yunani Koine (The Elements of New Testament Greek), ed. Lynne Newel, 2nd ed. (Malang: Seminari Alkitab Asia Tenggara, 1987), 77.
}

parallel tersebut hendak menyatakan bahwa pertambahan jiwa yang diakibatkan oleh peristiwa Pentakosta tersebut adalah suatu kejadian yang dinamis, yang sebelumnya pernah terjadi ledakan tiga ribu jiwa, dan akan terus mengalami pertambahan. Secara singkat dapat dijelaskan bahwa Lukas menekankan pada aspek dinamika yang sudah tentu tidak

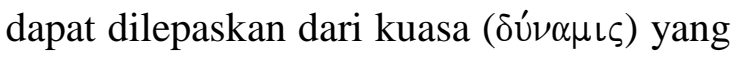
diperoleh melalui peristiwa Pentakosta. Kata dunamis tersebut memiliki padanan kata dengan kata "dinamis, dinamika", yang berarti bahwa kata dunamis menunjuk kepada kuasa yang menghasilkan dinamika dalam pribadi orang percaya. ${ }^{15}$ Dinamika itu sendiri menurut KBBI didefinisikan sebagai "gerak, menggerakkan, semangat". ${ }^{16}$ Lukas membingkai perikop dengan tensis yang menyimbolkan dinamika yang dihasilkan dari peristiwa Pentakosta.

$$
\text { Ayat } 41 \text { dan 47c juga }
$$
menyampaikan gagasan yang sama, yaitu pertambahan jiwa orang yang percaya atau orang yang diselamatkan. Meskipun sama, namun gagasan tersebut disampaikan

\footnotetext{
${ }^{15}$ Harls Evan R. Siahaan, "Karakteristik Pentakostalisme Menurut Kisah Para Rasul," DUNAMIS: Jurnal Teologi dan Pendidikan Kristiani 2, no. 1 (November 4, 2017): 12-28, accessed February 28, 2018, http://sttintheos.ac.id/ejournal/index.php/dunamis/article/view/132/116.

16 "Hasil Pencarian - KBBI Daring," accessed February 28, 2018, https://kbbi.kemdikbud.go.id/entri/dinamika.
} 
dengan intesitas yang semakin meningkat. Ayat 41 menyajikan fakta bertambahnya jiwa dalam satu hari, sedangkan dalam ayat $47 \mathrm{c}$ menyajikan pertambahan jiwa setiap harinya. Naiknya intesitas tersebut merupakan suatu hal yang lazim dalam sastra Ibrani, dimana kesamaan yang ditemukan dari parallel dari dua bagian tidaklah berarti sepenuhnya sama, namun selalu bagian pertama lebih kecil intensitasnya dibandingkan bagian kedua atau sebaliknya. ${ }^{17}$ Kenaikan intensitas tersebut dapat diartikan sebagai suatu cara dari penulis untuk menyampaikan suatu kemajuan yang bersifat dinamis.

Pada hari Pentaskosta jumlah orang yang menjadi percaya dan dibaptis bertambah kira-kira tiga ribu jiwa (ay. 41). Jumlah jiwa yang diselamatkan kemudian tidak berhenti bertambah atau bahkan berkurang, sebaliknya secara dinamis berkembang hingga tiap-tiap hari bertambah jumlah orang yang diselamatkan (ay. 47c). Lukas menempatkan kedua ayat ini sebagai bingkai dari narasinya tentang kehidupan jemaat yang ada di Yerusalem. Melalui bingkai tersebut Lukas hendak menyampaikan bahwa hidup jemaat mulamula yang ideal tersebut tidaklah terlepas

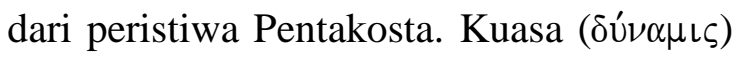

\footnotetext{
${ }^{17}$ Temper Longman III, Bagaimana Menganalisa Kitab Mazmur, 5th ed. (Malang: Literatur SAAT, 2007), 115-116.
}

yang dikaruniakan melalui Roh Kudus yang diterima telah membuat suatu ledakan jumlah orang percaya dan secara dinamis terus bekerja untuk menambahkan jiwa-jiwa baru. ${ }^{18}$

Korespondensi antara B dan B' dengan mudah dapat terlihat melalui kata

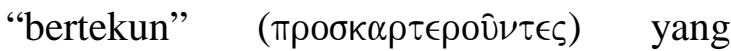
terdapat di dalam kedua bagian tersebut, yang juga menggunakan tensis participle present pada kedua bagian tersebut. Sebagaimana bagian A/A', kata "bertekun" juga mengalami perluasan, di mana jika pada B hanya menggunakan kata “bertekun" saja, maka pada B' diperluas dengan menambahkan frase "setiap hari" $(K \alpha \theta$ ' ì $\mu \epsilon \rho \nu)$ dan juga frase “dengan sehati" (ó $\mu \circ \theta \nu \mu \alpha \delta$ ò $\nu)$. Kenaikan intensitas atau perluasan yang digunakan juga dalam bagian B/B' tersebut kembali menekankan pada sifat dinamis yang bersumber dari kuasa yang diperoleh pada hari Pentakosta tersebut.

B dan B' juga parallel dalam gagasannya mengenai dua relasi, yaitu relasi horizontal dan relasi vertical. Relasi vertical berhubungan dengan ketekunan jemaat di Bait Allah, dalam pengajaran

\footnotetext{
${ }^{18}$ Yohanes Asin, "KARUNIA-KARUNIA ROH KUDUS SEBAGAI FAKTOR PENDORONG (PROMOTING FACTOR) PERTUMBUHAN GEREJA," Jurnal Antusias 1, no. 3 (September 1, 2011): 101-108, accessed February 25, 2018, http://sttintheos.ac.id/ejournal/index.php/antusias/article/view/78/77.
} 
para rasul, dalam doa-doa, dan dalam memuji Tuhan. Sedangkan relasi horisontal berkaitan dengan ketekunan dalam persekutuan, dalam memecahkan roti, dalam berbagi makanan, dan disukai oleh semua orang. Gagasan pada bagian B' juga mengalami peningkatan intensitas dibandingkan dengan yang terdapat dalam bagian B ketika disebutkan bahwa mereka memecahkan roti dengan sukacita, dan juga dengan tulus hati mereka memuji Allah.

Struktur ayat 42 juga membentuk pola kiasme (menyilang) yang susunannya adalah sebagai berikut:

a : dalam pengajaran para rasul (plural)

b : dan dalam persekutuan (singular)

b' : dan dalam memecahkan roti (singular)

a' : dan dalam doa-doa (plural)

Lukas memisahkan bagian-bagian tersebut

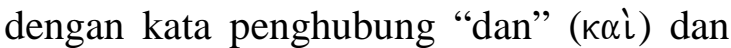
artikel definitive $\tau \hat{n}$. Melalui petunjuk inplisit tersebut pembaca segera dapat mengenali bagian-bagiannya dan sekaligus membentuk pola strukturnya. Bagian a dan a' parallel dalam kegiatan yang bersifat vertical dan sekaligus sejajar dalam kata benda jamak yang digunakan. Bagian $b$ dan b' berkorespondensi dalam bentuk kegiatan yang bersifat hubungan horizontal dan dalam penggunaan kata benda tunggal.

Penulis menyusun kalimat-kalimat ayat 42 sedemikian rupa sehingga menempatkan ketekunan di dalam pengajaran para rasul dan dalam doa-doa sebagai bingkai dari keseluruhan ayat 42 tersebut. Orang-orang yang percaya tersebut bertekun dalam pengajaran $(\delta\llcorner\delta \alpha \chi \hat{\eta})$ para rasul. Kata $\delta\llcorner\delta \alpha \chi \eta$ tersebut hampir tidak dapat dipisahkan dari khotbah para rasul di muka umum yang berbicara tentang keselamatan di dalam Yesus. ${ }^{19}$ Kata tersebut muncul dan digunakan juga dalam beberapa pemberitaan tentang Kristus (bd. 5:28; 13:12; 17:19). Dengan demikian pengajaran yang diterima oleh jemaat mula-mula bukanlah berisi ajaran motivasi-motivasi hidup popular pada zamannya yang mendorong jemat untuk memiliki kepedulian sosial, namun ajaran yang didominasi oleh proklamasi keselamatan di dalam Yesus. Para rasul benar-benar menyampaikan khotbah yang berisikan pengajaran, yaitu khotbah yang memberikan pemahaman tentang Allah yang berkarya dan perilaku umat yang sesuai dengan karya Allah, berbeda dengan khotbah kontemporer yang bersumber pada keinginan/ emosi manusia. ${ }^{20}$ Roh Kudus yang diterima oleh para murid telah

\footnotetext{
${ }^{19}$ C.K. Barrett, A Critical and Exegetical Commentary on the Acts of the Apostles, 3rd ed. (London: T\&T Clark Ltd, 2004).

${ }^{20}$ Kevin Tonny Rey, "Khotbah Pengajaran Versus Khotbah Kontemporer," DUNAMIS: Jurnal Penelitian Teologi dan Pendidikan Kristiani 1, no. 1 (September 1, 2016): 31, accessed March 8, 2018, http://sttintheos.ac.id/e-

journal/index.php/dunamis/article/view/100.
} 
menjadikan pengajaran yang mereka sampaikan menarik antusiasme jemaat untuk terus mau mendengarkan dan melaksanakan apa yang diajarkan tersebut. $^{21}$

Selain bertekun di dalam pengajaran para rasul, jemaat juga bertekun dalam doa $(\pi \rho 0 \sigma \in \cup \chi \alpha i \varsigma \varsigma)$. Kata $\pi \rho 0 \sigma \epsilon \cup \chi \alpha \hat{\imath} \varsigma$ merupakan bentuk jamak dari

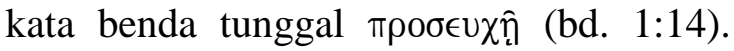
Penggunaan bentuk jamak tersebut menunjukkan bahwa doa jemaat mulamula tersebut berbeda dengan doa muridmurid Yesus ketika menantikan Roh Kudus. Ketika murid-murid Yesus menantikan Roh Kudus, mereka bertekun dalam satu doa, yaitu meminta karunia yang dijanjikan. Sedangkan bentuk plural dari doa jemaat mula-mula berarti bahwa mereka berdoa akan banyak hal yang mereka alami. Mereka bertekun dalam doa dan menaikkan berbagai doa yang menunjukkan bahwa peristiwa Pentakosta telah mentransformasikan orang-orang percaya untuk memiliki gaya hidup berdoa. $^{22}$

\footnotetext{
${ }^{21}$ Nur Budi Santosa, "Peran Roh Kudus Dalam Pelaksanaan Pendidikan Kristen," Jurnal Antusias 2, no. 2 (September 1, 2012): 105-118, accessed March 4, 2018, http://sttintheos.ac.id/ejournal/index.php/antusias/article/view/36/35. ${ }^{22}$ Daniel Sutoyo, “Allah Memanggil Umat-Nya Untuk Menjadi Gereja Yang Tekun Berdoa Menurut Kisah Para Rasul 4: 23 - 31," DUNAMIS. Jurnal Teologi dan Pendidikan Kristiani 1, no. 1 (September 1, 2016): 52-73, accessed March 4,
}

Penempatan kegiatan-kegiatan yang bersifat membangun relasi secara vertical tersebut pada bingkai dari keseluruhan teks ayat 42 dimaksudkan oleh penulis untuk menunjukkan bahwa kegiatan yang membangun relasi horizontal (b/b') bukanlah bersumber dari adanya ikatan emosional namun bersumber kepada kualitas spiritual yang dibangun melalui berbagai aktivitas rohani tersebut. Landasan spiritual yang kuat tersebut menghasilkan pelayanan sosial yang kuat yang juga menjadi ciri pelayanan gereja masa kini. ${ }^{23}$ Penulis menggunakan kata benda tunggal pada bagian $b$ dan b' dengan tujuan untuk menekankan pada aspek kesatuan yang kuat dalam relasi jemaat secara horizontal.

Bentuk relasi horizontal pertama yang ditunjukkan oleh kehidupan jemaat mula-mula adalah ketekunan mereka dalam persekutuan. Persekutuan

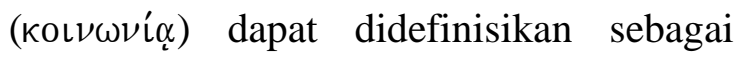
suatu hubungan antar-individu dalam kerangka kepentingan bersama dengan melibatkan peran aktif dalam

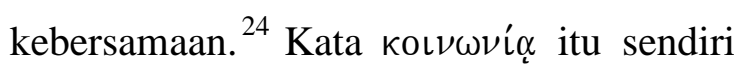

2018, http://sttintheos.ac.id/ejournal/index.php/dunamis/article/view/101/97. ${ }^{23}$ Nur Budi Santosa, "Pelayanan Sosial Sebagai Konteks Refleksi Aktivitas Misiologi," Jurnal Antusias 2, no. 4 (December 1, 2013): 126-137, accessed March 5, 2018, http://sttintheos.ac.id/ejournal/index.php/antusias/article/view/28/27.

${ }^{24}$ Daniel Sutoyo, "Gaya Hidup Gereja Mula-Mula Yang Disukai Dalam Kisah Para Rasul 2:42-47 
tidak digunakan dalam Kisah Para Rasul selain dalam 2:44 dan 4:32. Penggunaan kata tersebut dalam kitab lainnya dapat ditemukan dalam hubungannya dengan pengumpulan bantuan bagi orang-orang miskin (bd. Rm. 15;26; 2 Kor. 8:4; 9:13). Dengan demikian dapat disimpulkan bahwa bentuk persekutuan yang dipraktikkan oleh jemaat mula-mula bukanlah sekedar kesatuan dalam suatu kelompok karena adanya kesamaan minat atau tujuan, namun suatu kesatuan yang didasari oleh kasih dan kemurahan hati.

Relasi horizontal yang kedua ditunjukkan dengan ketekunan dalam

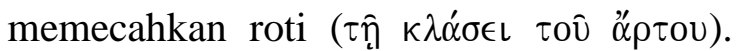
Kata $\kappa \lambda \alpha \dot{\sigma} \sigma \mathrm{L}$ (memecahkan) hanya digunakan dalam ayat ini dan dalam Lukas 24:35. Dalam Lukas 24:35 Yesus memecahkan roti di rumah murid yang ada di Emaus, dalam konteks jamuan makan yang mereka berikan kepada Yesus. Dengan demikian, tradisi "memecahkan roti" yang dilakukan oleh jemaat mulamula ini tidaklah sama dengan Perjamuan Kudus. Memecahkan roti dalam konteks Perjamuan Kudus sebagaimana yang digunakan dalam Lukas 22:19 adalah dengan kata $\kappa \lambda \alpha ́ \omega$. Namun demikian meskipun bukanlah Perjamuan Kudus, $\tau \hat{n}$

Bagi Gereja Masa Kini,” Jurnal Antusias 3, no. 6 (December 1, 2014): 1-31, accessed March 6, 2018, http://sttintheos.ac.id/ejournal/index.php/antusias/article/view/7/6

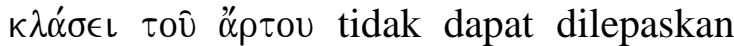
dari ekaristi apabila melihat konteks peristiwa kebangkitan Kristus dalam Lukas 24:35. Dengan menggunakan pilihan kata yang sama Lukas tentu hendak menyampaian pesan teologis yang sama diantara kedua praktik tersebut.

Praktik "memecahkan roti" tersebut bukanlah merupakan bentuk aktivitas makan bersama, namun adalah merupakan bagian pembukaan dari makan bersama dan sekaligus suatu pernyataan kasih dalam makan bersama. ${ }^{25}$ Pada akhirnya praktik ini menjadi suatu tradisi baru yang diperkenalkan oleh gereja untuk mengekspresikan kasih dalam hubungannya dengan kasih agape Kristus.

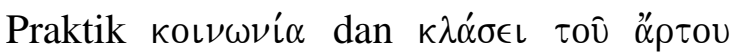
adalah dua hal yang berbeda dalam kesamaan. Berbeda dalam bentuknya kegiatannya, namun sama dalam faktor pendorongnya, yaitu kasih dalam persekutuan dengan Kristus. Inilah yang menjadikan dua praktik tersebut sejajar dalam strukturnya.

Sebagaimana bagian A mengalami kenaikan intensitas pada bagian A', demikian juga dengan $B^{\prime}$ (ay. $46-47 b$ ) adalah merupakan perluasan dari B. Selain perluasan dengan penambahan frase

\footnotetext{
${ }^{25}$ F.F. Bruce, The Acts of the Apostles: The Greek Text with Introduction and Commentary, $3 \mathrm{rd}$ ed. (Grand Rapids: William B. Eerdmans Publishing Company, 1990), 132.
} 


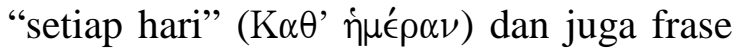

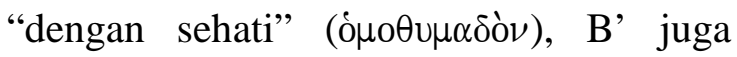
diperluas pada bagian-bagiannya. Struktur B' dapat disusun sebagai berikut:

a : dalam Bait Allah

b : dan memecahkan roti dari rumah ke rumah, berbagi makanan dalam sukacita

a' : dan dengan tulus hati mereka memuji Allah

b' : dan mereka mendapatkan kasih semua orang

Tidak jauh berbeda dengan bagian B, pada B' bagian-bagian kalimatnya ditandai

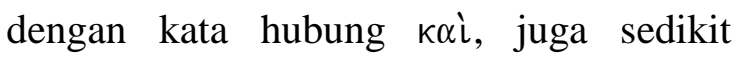
variasi dengan penggunaan $\tau \epsilon$, di mana keduanya memiliki pengertian yang sama, yaitu "dan".

Struktur B' berbeda pola dengan struktur B. Jika B berstruktur kiasme (menyilang), maka B' berstruktur simetris aba'b'. Pola simetris adalah merupakan pola terbuka karena dalam pola tersebut jika digambarkan seperti dua garis yang saling sejajar dan tidak ditemukan batasnya, berbeda dengan pola kiasme yang mirip dengan suatu bangunan berbingkai. Jika pada B pola kiasme tersebut bertujuan untuk membingkai relasi horizontal dengan kegiatan relasi vertical untuk menunjukkan dasar dari kegiatankegiatan sosial tersebut, maka pada B' pola simetris untuk menunjukkan bahwa baik aktivitas spiritual maupun aktivitas social adalah dua hal yang sejajar, yang memiliki nilai yang sama. Keduanya secara dinamis harus selalu berjalan seiring tanpa ada batasan periode. Objek keterangan pada setiap bagian B' juga menggunakan kata benda singular, yang semakin menegaskan kesatuan di antara dua jenis kegiatan tersebut.

Jemaat mula-mula bertekun dengan sehati setiap hari di Bait Allah ('€V $\tau \hat{\omega}$ $i \in \rho \omega)$. Lokasi yang menjadi tempat favorit jemaat tersebut berkumpul di Bait Allah adalah di serambi Salomo. ${ }^{26}$ Jemaat mulamula masih beribadah di Bait Suci, di mana ibadah mereka berpusat pada Perjamuan Tuhan. ${ }^{27}$ Bait Suci, terutama di Serambi Salomo, adalah tempat di mana orang-orang biasa mendengarkan pengajaran para rabi. ${ }^{28}$ Demikian halnya dengan yang dilakukan oleh para jemaat, mereka bertekun di dalam pengajaran para rasul sebagaimana disebutkan dalam ayat 42 dan di ayat 46 ini mendapatkan deskripsi yang lebih jelas tempat di mana mereka mendengarkan pengajaran tersebut. Penyebutan Bait Allah memberikan suatu penekanan tersendiri mengenai nilai

\footnotetext{
${ }^{26}$ Ibid, 133.

${ }^{27}$ J.I. Parker, Merrill C. Tenney, and William Jr. White, Ensiklopedi Fakta Alkitab: Bible Almanac2, 2nd ed. (Malang: Gandum Mas, 2004), 1123.

${ }^{28}$ Sutoyo, "Gaya Hidup Gereja Mula-Mula Yang Disukai Dalam Kisah Para Rasul 2:42-47 Bagi Gereja Masa Kini.”
} 
spiritual dari pengajaran para rasul tersebut.

Ketekunan berkumpul dalam Bait Allah (a) tersebut parallel dengan ketekunan dalam memuji Allah (a'). Bagian a' ini juga merupakan perluasan dari bagian a' pada ayat 42. Jika pada ayat 42 jemaat mula-mula bertekun dalam doadoa, maka a' pada bagian B' $^{\prime}$ ini memperluasnya melalui pujian kepada Allah yang dinaikkan dengan tulus hati

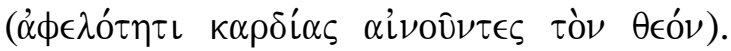

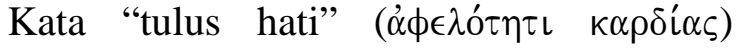
tersebut sebenarnya dapat diartikan sebagai rendah hati. Memuji Allah dengan kerendahan hati adalah merupakan suatu tindakan yang hanya dapat dilakukan oleh karya Roh Kudus. Tuhan Yesus mengatakan bahwa akan tiba waktunya orang-orang akan menyembah di dalam Roh dan kebenaran (Yoh. 4:21-24). Dalam Roh berarti suatu penyembahan yang dipimpin oleh Roh Kudus, dan dalam kebenaran berarti penyembahan yang menghormati Tuhan. ${ }^{29}$ Pentakosta telah mengubah ibadah lahiriah di Bait Allah menjadi ibadah dengan doa dan pujian yang memuliakan Allah. Hal tersebut sekaligus menjadi parallel yang kontras

\footnotetext{
${ }^{29}$ Eka Budhi Santosa, "Dinamika Roh Kudus Dalam Ibadah Pentakosta," Jurnal Antusias 2, no. 1 (January 5, 2012): 180-202, accessed March 9, 2018, http://sttintheos.ac.id/ejournal/index.php/antusias/article/view/68.
}

antara a dengan a', antara Bait Allah, yang dikenal dengan ibadah lahiriah dan legalismenya, dengan ibadah yang rendah hati di hadapan Allah.

Apabila a/a' dari bagian B' adalah merupakan parallel yang diperluas dari a/a' bagian $B$, maka b/b' bagian $B^{\prime}$ juga merupakan perluasan dari $b / b$ ' bagian $B$. Jika a/a' berbicara tentang relasi vertical, maka b/b' menyajikan fakta relasi horizontal. Pernyataan bahwa jemaat bertekun setiap hari dengan sehati memecahkan roti dari rumah ke rumah, berbagi makanan dalam sukacita (b) adalah perluasan dari bertekun dalam memecahkan roti (b') pada bagian B (ay. 42). Sebagaimana dijelaskan sebelumnya bahwa praktik memecahkan roti adalah ceremony pembukaan dari makan bersama, dan selanjutnya dalam ayat 46 ini dijelaskan bahwa mereka melakukannya secara bergiliran, dari rumah ke rumah. Lebih jauh lagi mereka melakukannya bukan hanya secara bergiliran namun juga berbagi makanan dengan sukacita.

Berbagi makanan tentu yang dimaksudkan adalah makan bersama (communal meal). Makan bersama bukanlah Perjamuan Tuhan, namun benarbenar adalah makan sebagaimana biasanya namun dilakukan bersama-sama dengan berbagi makanan yang ada. Yang menarik di sini Lukas menambahkan kata 


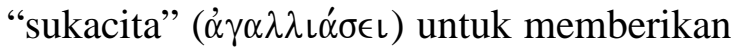
keterangan bagaimana suasana makan bersama tersebut. Berbagi makanan dengan sukacita sebenarnya ada dalam praktik perayaan Pentakosta dalam Perjanjian Lama (Ul. 16:10-12). Lukas nampaknya melihat parallel peristiwa Pentakosta dalam Perjanjian Lama dan Pentakosta dalam Perjanjian Baru sehingga kemudian juga menggunakan penggambaran suasana yang sama di antara kedua peristiwa tersebut. Dengan kata lain, penulis kembali hendak menekankan bahwa peristiwa Pentakosta itulah yang telah membuat jemaat hidup dalam kebersamaan dan dalam kesatuan yang kuat.

Relasi yang harmonis di antara jemaat tersebut kemudian berdampak pada kenyataan bahwa mereka mendapat kasih

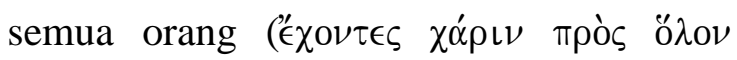

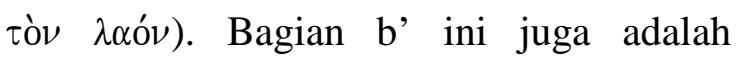
parallel dari b pada bagian B (ayat 42).

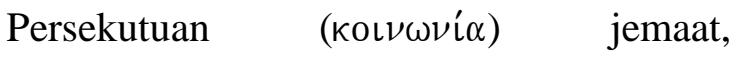
sebagaimana yang disebutkan dalam ayat 42, bukan sekedar ketekunan dalam perkumpulan biasa, namun ada kemurahan hati yang diwujudkan dengan berbagai pemberian atau sedekah. Hal inilah yang memberikan dampak bahwa mereka kemudian mendapatkan kasih dari semua orang.
Menarik apabila kemudian b/b' dari B dan b/b' dari B' disusun strukturnya seperti baris-baris puisi sebagai berikut:

dan dalam persekutuan (a) dan dalam memecahkan roti (b)

dan memecahkan roti dari rumah ke rumah, berbagi makanan dalam sukacita (b')

dan mereka mendapatkan kasih semua orang (a')

Susunan tersebut membentuk pola kiasme (menyilang) abb'a'. Perhatikanlah pada bingkai dari struktur tersebut, yaitu dalam persekutuan; mereka mendapatkan kasih semua orang, adalah parallel dalam menunjuk kepada aksi keluar, sedangkan dua baris yang ada di dalam parallel dalam menunjuk aksi ke dalam. Pada kedua baris yang menjadi bingkai tersebut persekutuan

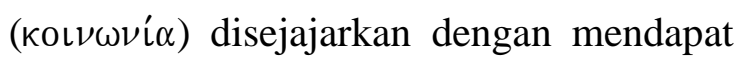
kasih semua orang. Lukas hendak memberitahukan kepada pembaca bahwa jemaat mula-mula bukan hanya dikenal baik hati kepada saudara seiman, namun juga kepada semua orang. Fakta bahwa mereka mendapatkan kasih dari semua orang tentu saja karena semua orang merasakan dan bukan hanya melihat kebaikan mereka. Kata koinonia yang dalam beberapa rujukan hanya dipakai untuk menunjuk kepada perbuatan memberikan sumbangan menjadi jawaban mengepa jemaat disukai oleh semua orang. Jemaat nampaknya memiliki kepedulian 
sosial yang tinggi, bukan hanya kepada saudara seiman namun juga kepada semua orang, dengan bertekun di dalam memberikan sumbangan (

Pada pusat struktur dari Kisah Para Rasul 2:41-47 (C/C') ada dua aksi yang parallel, yaitu aksi dari para rasul yang melakukan banyak mujizat dan tanda, dan aksi sosial jemaah. Bukan sebuah kebetulan juga bahwa Lukas menggunakan tensis imperfect di seluruh ayat 43-45 tersebut. Tensis imperfect tersebut memberikan suatu kesan bawah peristiwa yang terjadi tidak berhenti sampai pada waktu itu saja, namun terus berlangsung. Dengan demikian, bagian pusat dari struktur Kisah Para Rasul 2:41-47 hendak memberitahukan kepada pembaca bahwa dampak dari Pentakosta adalah dua aksi yang tidak terpisahkan, yaitu karunia Roh (mujizat dan tanda) dan buah Roh (kepedulian sosial, perbuatan baik). Kedua hal tersebut tidak terpisahkan dan akan terus berlangsung secara dinamis.

Para rasul mengadakan banyak mujizat dan tanda (ay. 43) yang kemudian membuat setiap jiwa menjadi takut. Kata "takut" (фóßos) tersebut dapat diartikan juga sebagai "hormat". Kata фóßos tersebut muncul juga beberapa kali dalam Kisah Para Rasul untuk menunjuk kepada reaksi atas kejadian supranatural yang dilakukan oleh para rasul (bd. 5:5, 11; 9:31; 19:17).

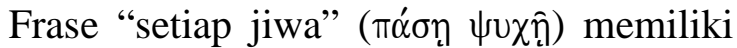

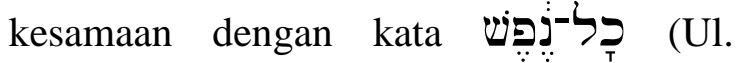
12:16), yang dalam versi Septuaginta digunakan juga frase yang sama. Dengan demikian, frase "setiap jiwa" tersebut memiliki arti yang sama dengan "setiap orang”. Banyak mujizat dan tanda yang dilakukan para rasul telah menimbulkan rasa hormat dan segan dari setiap orang kepada mereka.

Jemaat juga tidak ketinggalan untuk menunjukkan aksi nyata mereka sebagai orang-orang yang telah menerima Roh Kudus. Mereka bersatu dan memiliki semua kesamaan (ay. 44). Hal tersebut berarti bahwa mereka hidup sebagai satu komunitas orang yang percaya sehingga mereka senantiasa melihat kesamaankesamaan yang ada di antara mereka yang kemudian memperkuat kesatuan di antara mereka. Ayat 45 kemudian menjadi contoh nyata dari kesatuan mereka, di mana mereka, yang memiliki, menjual tanah maupun harta milik untuk kemudian hasilnya diberikan kepada mereka yang kekurangan. Tindakan tersebut pada akhirnya mengatasi kesenjangan sosial sehingga sebagaimana yang disampaikan dalam ayat 44 mereka memiliki semua kesamaan. Tidak ada hukum apapun yang mengatur mereka harus membagi-bagikan harta mereka kepada yang kekurangan. 
Mereka tergerak hatinya ketika ada yang dalam kekurangan.

\section{Hasil Analisis Struktural}

Melalui analisis struktural terhadap teks Kisah Para Rasul 2:41-47 tersebut dapat dijelaskan dua hal. Pertama, dua pasang bagian yang mengelilingi pusat struktur (A/A' dan B/B') selalu parallel dengan intensitas yang menanjak. Hal itu diartikan sebagai cara Lukas untuk

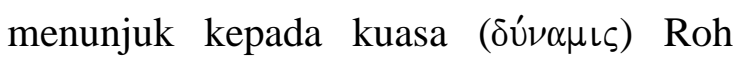
Kudus, yang dalam hal ini erat kaitannya dengan dengan dinamika atau sesuatu yang dinamis, yang menjadi bingkai dari aksi para rasul dan jemaat yang ada pada pusat struktur. Kedua aksi pada pusat struktur tersebut hanya dapat dilakukan dalam bingkai Pentakosta.

Kedua, pusat struktur teks tersebut adalah memperhadapkan dua jenis aksi yang berbeda, yaitu tanda dan mujizat yang dilakukan oleh para rasul dan aksi sosial jemaat. Kedua aksi tersebut tepat berada pada pusat perikop cara hidup jemaat mula-mula. Hal tersebut dapat diartikan bahwa tanda-tanda, mujizatmujizat dan aksi sosial adalah dua hal yang secara ideal harus ada dalam gereja untuk dapat menghasilkan pertumbuhan jiwa yang dinamis. Pentakosta memampukan dan menggerakkan jemaat untuk melakukan kedua aksi tersebut secara bersamaan dan seimbang.

\section{KESIMPULAN}

Pentakosta telah mengubah muridmurid Yesus secara kuantitas maupun secara kualitas. Secara kuantitas jumlah mereka yang sebelumnya seratus dua puluh orang saja (bd. Kis. 1:15) menjadi ribuan orang dan bahkan terus menerus mengalami pertambahan jumlah dari hari ke hari. Hal pertumbuhan jiwa yang dimanis inilah yang menjadi ciri khas dari gerakan Pentakostalisme. Memang Tuhan lah yang berkuasa untuk menambahkan jiwa-jiwa, namun itu semua dapat terjadi karena didukung dengan kualitas pribadi dari murid-murid dan jemaat mula-mula sebagai hasil dari karya Roh Kudus dalam hidup mereka.

Mereka menjadi pribadi yang dinamis, yang senantiasa bergerak dalam dua segi, secara bersamaan dan seimbang. Mereka membangun diri mereka secara seimbang, baik dalam relasi secara vertical maupun secara horizontal. Relasi secara vertical mereka bangun dengan bertekun di dalam pengajaran para rasul di Bait Allah. Mereka bertekun bukan karena mendengarkan khotbah-khotbah kontemporer atau khotbah motivasi, namun pengajaran-pengajaran hidup kekristenan. Mereka membangun rohani 
mereka juga dengan bertekun dalam berbagai doa dan memuji Tuhan dengan kerendahan hati. Relasi vertical mereka bangun melalui persekutuan dan kesatuan yang mereka kerjakan dengan sukacita.

Relasi yang dibangun tersebut kemudian menghasilkan aksi yang berjalan seiring dan seimbang, yaitu aksi spiritual (proklamasi) dan aksi sosial (demonstrasi). Proklamasi Kerajaan Allah dilakukan melalui tanda-tanda dan mujizat-mujizat yang dilakukan oleh para rasul, sedangkan demonstrasi Kerajaan Allah melalui aksi sosial jemaat. Mereka yang kuat secara financial membantu mereka yang hidup dalam kekurangan dengan kerelaan hatinya sehingga tidak timbul kesenjangan sosial. Proklamasi dan demonstrasi Kerajaan Allah yang berjalan bersama dan tanpa dikotomi tersebut menjadi kunci perkembangan gereja. Hal itu membangkitkan sikap hormat dan kasih dari semua orang kepada gereja yang pada akhirnya memudahkan pertumbuhan jiwajiwa baru. Pada akhirnya, gerakan Pentakostalisme jika mengacu pengalaman gereja mula-mula di Yerusalem akan menekankan pelayanannya pada pelayanan dengan kuasa dan pelayanan sosial.

\section{DAFTAR PUSTAKA}

Asin, Yohanes. "KARUNIA-KARUNIA ROH KUDUS SEBAGAI FAKTOR PENDORONG (PROMOTING
FACTOR) PERTUMBUHAN GEREJA." Jurnal Antusias 1, no. 3 (September 1, 2011): 101-108. Accessed February 25, 2018. http://sttintheos.ac.id/ejournal/index.php/antusias/article/vie $\mathrm{w} / 78 / 77$.

Barrett, C.K. A Critical and Exegetical Commentary on the Acts of the Apostles. 3rd ed. London: T\&T Clark Ltd, 2004.

Bruce, F.F. The Acts of the Apostles: The Greek Text with Introduction and Commentary. 3rd ed. Grand Rapids: William B. Eerdmans Publishing Company, 1990.

Calloud, Jean. "A Few Comments on Structural Semiotics: A Brief Review of A Method and Some Explanation of Procedures." Semeia 15 (1979): 51-82.

Gnanakan, Ken. Teologi Misi: Kepedulian Kerajaan Allah. Edited by Yusak Tanasyah. Jakarta: YWAM Publishing Indonesia, 1995.

Longman III, Temper. Bagaimana Menganalisa Kitab Mazmur. 5th ed. Malang: Literatur SAAT, 2007.

Maggay, Melba Padilla. Transformasi Masyarakat: Refleksi Keterlibatan Sosial Kristen. Jakarta: Cultivate Publishing, 2004.

Parker, J.I., Merrill C. Tenney, and William Jr. White. Ensiklopedi Fakta Alkitab: Bible Almanac-2. 2nd ed. Malang: Gandum Mas, 2004.

Rey, Kevin Tonny. "Khotbah Pengajaran Versus Khotbah Kontemporer." DUNAMIS: Jurnal Penelitian Teologi dan Pendidikan Kristiani 1, no. 1 (September 1, 2016): 31. Accessed March 8, 2018. http://sttintheos.ac.id/ejournal/index.php/dunamis/article/vie $\mathrm{w} / 100$. 
Santosa, Eka Budhi. "Dinamika Roh Kudus Dalam Ibadah Pentakosta." Jurnal Antusias 2, no. 1 (January 5, 2012): 180-202. Accessed March 9, 2018. http://sttintheos.ac.id/ejournal/index.php/antusias/article/vie w/68.

Santosa, Nur Budi. "Pelayanan Sosial Sebagai Konteks Refleksi Aktivitas Misiologi." Jurnal Antusias 2, no. 4 (December 1, 2013): 126-137. Accessed March 5, 2018. http://sttintheos.ac.id/ejournal/index.php/antusias/article/vie w/28/27.

- "Peran Roh Kudus Dalam Pelaksanaan Pendidikan Kristen." Jurnal Antusias 2, no. 2 (September 1, 2012): 105-118. Accessed March 4, 2018. http://sttintheos.ac.id/ejournal/index.php/antusias/article/vie $w / 36 / 35$.

Siahaan, Harls Evan R. "Karakteristik Pentakostalisme Menurut Kisah Para Rasul." DUNAMIS: Jurnal Teologi dan Pendidikan Kristiani 2, no. 1 (November 4, 2017): 12-28. Accessed February 28, 2018. http://sttintheos.ac.id/e-

journal/index.php/dunamis/article/vie w/132/116.

Soesilo, Yushak. "Doktrin Oneness Pentacostalism." Jurnal Antusias 2, no. 1 (January 5, 2012): 53-67. Accessed March 4, 2018. http://sttintheos.ac.id/ejournal/index.php/antusias/article/vie w/60/59.

Sudjono, Andreas. "Pentakostalisme." Jurnal Antusias 1, no. 2 (May 1, 2011): 6-12. Accessed March 13, 2018. http://sttintheos.ac.id/ejournal/index.php/antusias/article/vie w/80/79.

Sutoyo, Daniel. "Allah Memanggil UmatNya Untuk Menjadi Gereja Yang Tekun Berdoa Menurut Kisah Para Rasul 4: 23 - 31." DUNAMIS: Jurnal Teologi dan Pendidikan Kristiani 1, no. 1 (September 1, 2016): 52-73. Accessed March 4, 2018. http://sttintheos.ac.id/e-

journal/index.php/dunamis/article/vie w/101/97.

-. "Gaya Hidup Gereja Mula-Mula Yang Disukai Dalam Kisah Para Rasul 2:42-47 Bagi Gereja Masa Kini." Jurnal Antusias 3, no. 6 (December 1, 2014): 1-31. Accessed March 6, 2018. http://sttintheos.ac.id/e-

journal/index.php/antusias/article/vie $\mathrm{w} / 7 / 6$.

-. Gerakan Pentakostalisme: Sejarah Kebangunan Rohani Yang Mewarnai Dunia Dan Injil Bagi Bangsa-Bangsa. Sukoharjo: Born Win's Publishing, 2011.

Tarmedi, P. A. Didi. "Analisis Naratif: Sebuah Metode Kristiani Hermeneutika Kitab Suci." MELINTAS 29, no. 3 (July 14, 2014): 331-360. Accessed February 25, 2018.

http://journal.unpar.ac.id/index.php/m elintas/article/view/902/889.

Wenham, J.W. Bahasa Yunani Koine (The Elements of New Testament Greek). Edited by Lynne Newel. 2nd ed. Malang: Seminari Alkitab Asia Tenggara, 1987.

"Hasil Pencarian - KBBI Daring." Accessed February 28, 2018. https://kbbi.kemdikbud.go.id/entri/din amika. 